\title{
Measurement of Kampung Performance as Basic Strategy Towards a Resilient City: Evidence from CASBEE-UD and LEED-ND`s Results
}

\author{
Muhammad Sani Roychansyah ${ }^{1}$ \\ ${ }^{1}$ Department of Architecture and Planning, Universitas Gadjah Mada, Indonesia \\ saniroy@ugm.ac.idor saniroy@gmail.com
}

\begin{abstract}
Urban kampung is body and soul of Indonesia urban structure and life. It has vital roles for social, economy, and physical strategies, including a resilient city strategy. That is why kampung oriented development (KOD) would be inevitably an underlying model to bring kampung towards sustainable urban development. As an investigation step, it is important to assess their environmental performance conditions, using popular and leading sustainable building and assessment tools to measure the conditions of existing urban kampungs. (Comprehensive Assessment System for Building Environmental Efficiency for Urban Development)and LEED-ND (Leadership in Energy \& Environmental Design for Neighborhood Development) are chosen and applied to critically observe the kampung environment conditions comprehensively. Results showed in average that the urban kampungs in term of environmental performance based on both CASBEE-UD and LEED-ND category are still quite far from the ideal criteria. These results significantly steer a road map of strategies related to kampung oriented development (KOD).
\end{abstract}

Keywords: compactness, kampung oriented development, CASBEE-UD, LEED-ND

\section{Introduction}

In Indonesia, kampungs are inevitably an integral part of both urban spatial structure and urban life. They are body and soul, where the cities in Indonesia are growing and at the same time facing many problems in urban developments. Almost all aspects of urban life, whether social, cultural, political, and of course physical environment can be traced using kampung as a basis unit of analysis. However, up to now urban kampungs are still seen as less strategic to deal with recent urban development. Many people assume that by looking at a macro strategy in advance, all urban problems can be overcome. In fact, this assumption is not easy to realize and often the outcomes are difficult to be traced through the most representative unit of the city, the urban kampungs.

Coincided with the importance of sustainability in urban development, indeed the urban kampungs should have a crucial role as a backbone of implementation issues for urban sustainability. Because of its role, undoubtedly any initiation of sustainable urban development in Indonesia should need to think about the kampung as an entry point for the implementation. This fact has really showed the importance of the kampung as basis of the resilience city as well. Of course, traditionally there has been plenty of local knowledge that has been running well in the urban kampung. For example, how harmoniously living in dense residential or mixed-used of space that is lately suggested by the west, has always been present and growing in the kampungs for a long time. Thus, our task now is to try to formulate how actually universal values of sustainable urban development such as high population density, high activity concentration, optimal urban size than can easily control the environment, supported system for a good mobility, and achievement of good welfare, can be integrated in the developments inside the kampungs.

On the other hand, recently the urban kampungs are also experiencing many changes, although urban stakeholders were more understood that urban development in Indonesia 
should be oriented to the kampung (Kampung Oriented Development). How big potentials and problems of the kampungs in delivering sustainable development in urban areas in Indonesia is still not much revealed. This is due to absence of a comprehensive measurement tool to determine the condition of the actual kampungs. Therefore, this paper has aim to measure performances of the kampungs by using assessment tools which have been widely used in the world. In this paper, since extensive use of these two assessment tools, CASBEEUD (Comprehensive Assessment System for Building Environmental Efficiency for Urban Development)and LEED-ND (Leadership in Energy \& Environmental Design for Neighborhood Development), will be applied to measure the performance of the kampungs, The results of this measurement are empirically expected to steer the direction of the kampung oriented development (KOD) more focus.

\section{Materials and Method}

\subsection{Kampung Oriented Development as a Resilient Concept}

As considerable beliefs, kampungs in Indonesia really take an important role substantially in the process of urban development. As informal or popular settlement sectors in other developing countries, the urban kampung settlements have provided serviceable and affordable shelter for a majority of Indonesian urban households, more than 80\% (McGee, 1996). As some researchers (for example Guiness, 1986; Nas, 1987; Setiawan, 2003) stated, kampungcomprehensively represents a dynamic process by which groups of people-mostly the poor--provide their own housing, control their environments, and engage in collective efforts or mutual assistances (gotong royong) to improve their lives. On the contrary, the urban kampungs from perspective of Indonesian government has been neglected as potential resource and confirmed as impermanent solution to cope with recent housing and other development problems.

Kampung Oriented Development (KOD) model has been arranged as an idea of implementation for compactness development in YogyakartaCity (Roychansyah and Diwangkari, 2009). Basically it can be seen from two considerations. Firstly, structurally the urban kampungs as described above have a significant role in broad range of dimensions in the urban structure. The structure of the kampungs in spatial structure of city's core is also intentionally clear to state that the urban kampung for the urban development model in Indonesia might be a permanent solution, not a temporal solution. Secondly, the urban kampungs have experienced historically with many schemes of development. Although it contains several weaknesses, Kampung Improvement Program (KIP) is widely known as a masterpiece of successful program in the Indonesian kampungs. However, KIP is only focused on an infrastructure upgrading program for the kampung based on the needs of installation and improvement for roads, pathways, water supplies, drainage, and sanitation. Assumption that the idea of improvement of limited housing and infrastructure would also stimulate the improvement of socio-economic conditions in the kampung communities, should be reviewed again.

In Roychanyah (2008), based on the analysis of compactness performaces, the urban kampungs conditions have a good tendency for both high population and built environment density, as well as good performance for delivering mixed-use in various urban functions. Traditionally, they have already showed as part of urban physical, socio-economic, and culture entity. They are able to be seen as an entry point for the implementation of resilient city ideas, mainly from their strengths in environmental density and mixed used of the urban space potentials. Based on Newman et al. (2009), a compactness condition of environment will be in line with degree of resilience of the city, especially from perspective of energy use. 
A resilient city through its compact and mixed-use urban environment, by contrast, is also far more efficient in its demand for municipal services and infrastructure requirements.

Supporting this argument, the condition of many kampungs is getting worsened today, passing their optimum capacity of their environments, if viewed from their standard of quality of life (dominantly indicated with uncontrolled population density, lack of open space, environmental degradation, emerging many slum areas, and so forth). An urgency to redevelop the urban kampungs as further step in the re-improvement of the kampung condition becomes a realistic and an arguable idea towards a concept of resilient city. Kampung oriented development (KOD) as shown in Figure 1 systematically is a strategic attempt through a comprehensive policy using the urban kampungs as focus area of development that encompasses several intensive developments based on characteristics of kampungs as integral part of urban structure (in this case based on Yogyakarta City's condition, Indonesia), like transit oriented development, people oriented development, access oriented development, and activity oriented development. All of these developments are fundamentally framed sustainable oriented development principles. Every single theme of development is dedicated to a specific characteristic of the kampung.

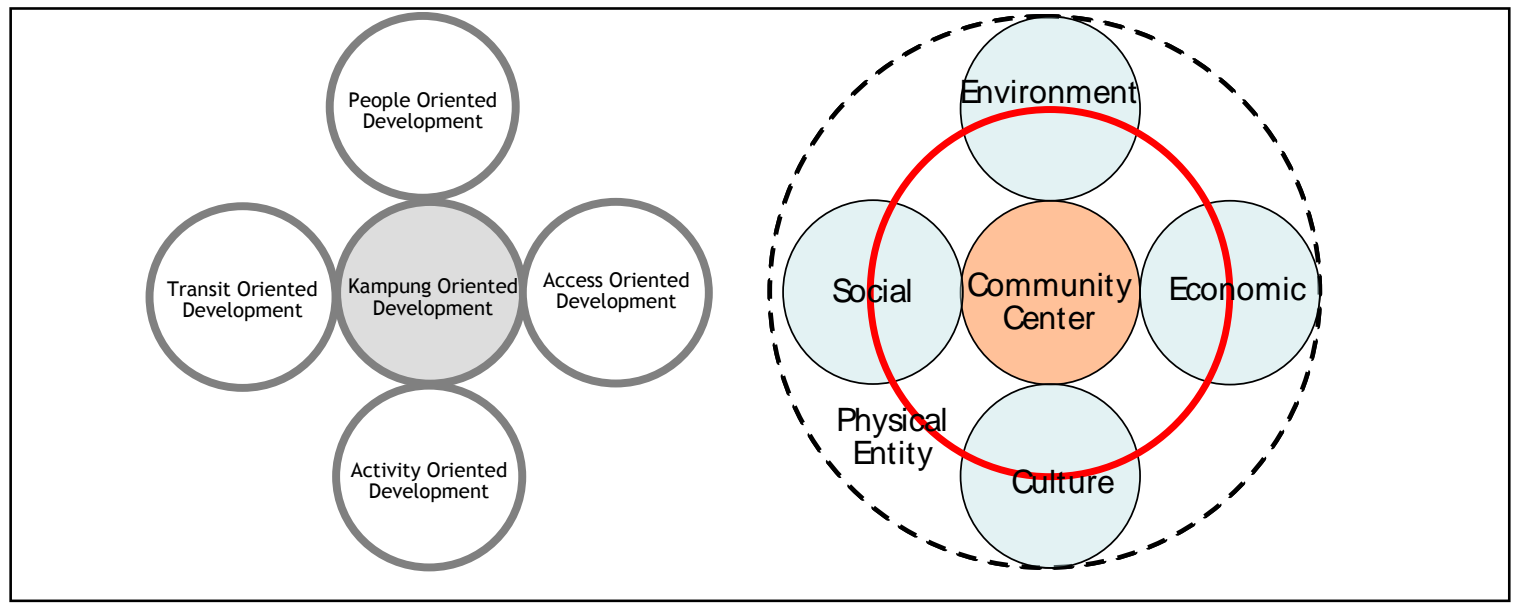

Figure 1: Kampung Oriented Development (KOD) embraces some empowerment programs of the kampung (left) and four important considerations of sustainability in KOD (right) Source: (Roychansyah, 2008)

\subsection{Kampung Measurement: Application of CASBEE-UD and LEED-ND}

To deal with a resilient concept, this paper is aimed to investigate the urban kampung performances empirically based on a standardized assessment tools. In this case CASBEE-UD and LEED-ND is used together to comprehensively observe and consistently assess the conditions. CASBEE-UD (Comprehensive Assessment System for Building Environmental Efficiency for Urban Development) and LEED-ND (Leadership in Energy and Environmental Design for Neighborhood Development) both are environmental assessment systems that provide a methodology for scoring or rating an environmental effects, energy-resource consumption, and health impacts, similar to other tools popularly used in the world. Despite all of these tools have quite same goals, but in general clearly these assessments can be a very complicated process because each of these effects has different units of measurements and affects different physical areas (Kawazu et al., 2005). CASBEE-UD has been developed in Japan, while LEED-ND was initially launched in the end of 2007 (IBEC, 2007; USGBC, 2011). 
Both have been developed from the initial program that is more focused on single building measurement.

CASBEE for Urban Development is an environmental performance assessment tool for whole groups of buildings (urban scale), focusing on the phenomena that can accompany the conglomeration of buildings, and the outdoor spaces around the buildings. It is also a standalone system, independent of the previous building-scale CASBEE. CASBEE-UD excludes the interior of buildings from assessment (although there are exceptions in some assessment items), therefore the configuration makes it possible to evaluate an area of development as a whole within designated area. It considers and calculates QUD (environmental quality in urban development) and LRUD (load reduction in urban development). QUD completely covers natural environment (microclimates and ecosystems), service functions for the designated area, and contribution to the local community (history, culture, scenery, and revitalization), while LRUD accommodates environmental impact (on microclimates, facade and landscape), social infrastructure, and management of the local environment. As results of CASBEE-UD assessments are ranked in five grades: Excellent (S), Very Good (A), Good (B+), Fairy Poor (B-) and Poor (C) (IBEC, 2007).

Table 1: Characteristics of the Measured Kampungs

\begin{tabular}{|c|c|c|c|c|c|}
\hline No & Aspect & Kampung A & Kampung B & Kampung C & Kampung D \\
\hline 1. & Name & $\begin{array}{l}\text { Kampung } \\
\text { Terban Utara }\end{array}$ & $\begin{array}{l}\text { Kampung } \\
\text { Ledok Terban }\end{array}$ & Kampung Cokrodirjan & $\begin{array}{l}\text { Kampung } \\
\text { Prawirodirjan }\end{array}$ \\
\hline 2. & Administrative & $\begin{array}{l}\text { Kelurahan } \\
\text { Terban, Kecamatan } \\
\text { Gondokusuman }\end{array}$ & $\begin{array}{l}\text { Kelurahan } \\
\text { Terban, Kecamatan } \\
\text { Gondokusuman }\end{array}$ & $\begin{array}{l}\text { Kelurahan } \\
\text { Suryatmajan, } \\
\text { Kecamatan Danurejan }\end{array}$ & $\begin{array}{l}\text { Kelurahan } \\
\text { Prawirodirjan } \\
\text { Kecamatan } \\
\text { Gondomanan }\end{array}$ \\
\hline 3. & Location & $\begin{array}{l}\text { Central city, around } \\
500 \text { m east of Tugu } \\
\text { Yogyakarta. }\end{array}$ & $\begin{array}{l}\text { Central city, around } 500 \\
\text { m east of Tugu } \\
\text { Yogyakarta. }\end{array}$ & $\begin{array}{l}\text { Central city, around } \\
500 \text { m east of } \\
\text { Malioboro Street } \\
\text { Yogyakarta } \\
\end{array}$ & $\begin{array}{l}\text { Central city, around } \\
500 \text { m east of } \\
\text { Kraton Yogyakarta }\end{array}$ \\
\hline 4. & HH number & 58 HHs (1 RT) & 60 HHs (3 RT) & 82 HHs (3 RT) & 76 HHs (3 RT) \\
\hline 5. & Characteristics & $\begin{array}{l}\text { It represents best } \\
\text { practice of kampung } \\
\text { development. } \\
\text { Established by } \\
\text { renowned architect, } \\
\text { Romo Mangun, and } \\
\text { still well maintained } \\
\text { environment today. } \\
\text { It is located at the } \\
\text { northern riverbank } \\
\text { of the Code River of } \\
\text { Yogyakarta City } \\
\text { with easy access to } \\
\text { surroundings area. } \\
\text { It becomes a } \\
\text { tourism destination } \\
\text { in the city. }\end{array}$ & $\begin{array}{l}\text { It represents a natural } \\
\text { type of kampung } \\
\text { without any } \\
\text { improvement programs } \\
\text { yet. The condition tends } \\
\text { to be a slum. It is located } \\
\text { at the northern } \\
\text { riverbank of the Code } \\
\text { River of Yogyakarta } \\
\text { City, just over the best } \\
\text { practice location, but } \\
\text { with less access to } \\
\text { surrounding } \\
\text { environment. This } \\
\text { kampung can also } \\
\text { describe the situation of } \\
\text { best practice before } \\
\text { interaction with Romo } \\
\text { Mangun. }\end{array}$ & $\begin{array}{l}\text { It represents a } \\
\text { kampung that has } \\
\text { been changed by } \\
\text { improvement } \\
\text { program (vertical } \\
\text { public housing). Some } \\
\text { residents have moved } \\
\text { to vertical leased } \\
\text { housing built in this } \\
\text { area. It is located at } \\
\text { central riverbank of } \\
\text { Code River of } \\
\text { Yogyakarta City. The } \\
\text { mix of residents } \\
\text { between native and } \\
\text { newcomer is } \\
\text { relatively big } \\
\text { compared to the other } \\
\text { location. }\end{array}$ & $\begin{array}{l}\text { It also represents a } \\
\text { natural type } \\
\text { kampung without } \\
\text { any improvement } \\
\text { program yet. The } \\
\text { difference between } \\
\text { the second } \\
\text { kampung`s } \\
\text { condition is in } \\
\text { easier access to be } \\
\text { connected to } \\
\text { surrounding } \\
\text { environments and } \\
\text { geographically not } \\
\text { in a too steep } \\
\text { riverbank. This } \\
\text { kampung also has } \\
\text { more mix condition } \\
\text { of residents } \\
\text { background. }\end{array}$ \\
\hline
\end{tabular}

Source: (Author, 2011)

Furthermore, LEED for Neighborhood Development is a rating system that integrates the principles of smart growth, sustainable urbanism, and green building for neighborhood design. Since LEED for Neighborhood Development certifies projects that may have significantly longer construction periods than single buildings, LEED-ND differs from other commercial and residential LEED rating systems as it has three stages of certification, which 
relate to the phases of the real estate development process (stage 1 as conditionally approved plan, stage 2 as pre-certified plan, and stage 3 as certified plan in a completed project). LEED-ND rating point system is similar to the other previous LEED family such as certified, silver, gold, and platinum ranks. Major credit categories of LEED-ND comprise smart location and linkages, neighborhood pattern and designs, green infrastructure and buildings, and additional consideration on innovation and design process (USGBC, 2011). However, unlike CASBEE-UD that tries to put social related performance into consideration system, LEED-ND seems more focused on physical performance and environmental design.

Regarding the case of measurement, Yogyakarta City located in Central Java is undertaken as object to show some significance potentials in delivering a kampung oriented development (KOD). The city itself was founded in 1756 and its kampungs have traditionally clustered together as important part of community settlements in the urban structure. Based on 2010 data, population of Yogyakarta City is about 390 thousand, while the population density is about 120 persons/ha (Biro Statistik Yogyakarta, 2010). It is distributed differently in 14 wards (kecamatan). There is a ward with 100 persons/ha, contrary there is also a ward with more than 200 persons/ha. This population density is more than enough as main consideration of population densification of compactness attributes. Consequently, this condition also brings high density in built urban areas, with very dense space settlements, lack of open space, and dominated by irregular patterns of buildings and pathways.

This paper will show some empirical considerations taken into account to carry out KOD through kampung environment efficiency performance. The CASBEE-UD and LEED-ND measurements have been conducted in 4 types of kampungs along the Code River, located in the city center as described in Table 1. The riverbanks of these areas are usually used to informally reside with high density population. Dominantly they work as informal sector workers in Yogyakarta City and surrounding areas. Today, in these riverbanks of Code River there are 3 vertical leased public housings (rusunawa) namely Jogoyuda, Cokrodirjan, and Juminahan public housing. There are noinitiatively follow-up programs tried to be combined with relocating kampung residents into those new vertical housingssuch as public space or engagement space for economic activities. How environment performance really expresses kampungs condition, people only judge without any valid assessment procedure. From this point of view, the primarily step would be very reasonable to understand measurement results based on a standardized assessment tool. Then, the results would be beneficial for further steps of improvements toward objective of KOD itself.

Technically, all of these kampungs are drawn in GIS basemap format to ease data overlays, including physical data of the kampungs, such as site area, building coverage, floor ratio, etc. The next step is to analysis the condition of the kampungs characteristics related to environmental performance criteria developed in CASBEE-UD and LEED-ND within a standard version. Completely, all the data are elaborated in CASBEE-UD and LEED-ND sheets to result clear presentation of the characteristics of environmental considerations in the designated areas. As shown by Roychansyah (2009), the initial use of CASBEE-UD for measuring kampung performance could produce a thorough analysis to help formulating a suitable strategy in the kampung oriented development. In this paper, additional analysis of the use of LEED-ND is expected to be increasingly able to give a detail consideration for future policy priorities for the concept of KOD. 


\section{Result and Discussion}

Comprehensively, the assessment results sheet of CASBEE-UD presents the results for QUD (environmental quality in urban development), LRUD (outdoor environmental loads in urban development) and BEEUD (building environmental efficiency in urban development), both numerically and graphically. Related information on the designated project is summarized and presented on one sheet, so that it is easy to identify CASBEE for Urban Development assessment results at a glance. To give more complete descriptions, comparatively important points of the results can be seen at Table 2. Based on CASBEE criterion, all kampungs can not exceed medium level of each category of QUD and LRUD (3 of 5). Generally, from these results, environment efficiency performances of case studied kampungs are low. There are no significant differences of BEE result between kampungs with small piece of administrative areas (Kampung Terban Utara and Kampung Ledok Terban with less than 1 ha of area) with kampungs which have bigger piece of administrative areas (Kampung Prawirodirjan with about 9 ha and Kampung Cokrodirjan with about 3 ha). All reached BEE-UDs are no more than 1 or classified into B- which means fairly poor condition. Based on eco efficiency concept (Murakami, 2008), these results classify into less sustainable condition.

Furthermore, regarding QUD that comprises QUD-1 natural environment, QUD-2 service functions for the designated area and QUD-3 contribution to the local community, all case studies show under normal boundary of good result target (3). Among these QUD, QUD3 can significantly strengthen an important role of kampung to the local communities. Likewise, for LRUD that embraces LRUD-1 environmental impact on microclimates, facade and landscape, LRUD-2 social infrastructure and LRUD-3 management of the local environment, in average they have produced unsatisfactory results. For instance, they have very bad condition (no measures taken or no coordination) of transport planning or traffic load to quite good of initial activities in garbage treatment.

Table 2: Comparison of CASBEE Assessment Results among the Measured Kampungs

\begin{tabular}{|l|l|l|l|l|}
\hline Category & Kampung A & Kampung B & Kampung C & Kampung D \\
\hline Score of QL 1 & 2.9 & 2.5 & 2.6 & 2.1 \\
\hline Score of QL 2 & 2.6 & 2.9 & 2.4 & 2.1 \\
\hline Score of QL 3 & 4.2 & 3.0 & 3.0 & 3.2 \\
\hline Total Score of QL & 3.2 & 2.8 & 2.7 & 2.4 \\
\hline Score of LR 1 & 2.8 & 2.9 & 2.9 & 3.0 \\
\hline Score of LR 2 & 2.6 & 2.6 & 2.5 & 2.4 \\
\hline Score of LR 3 & 2.6 & 2.6 & 2.5 & 2.8 \\
\hline Total score of LR & 2.7 & 2.7 & 2.6 & 2.7 \\
\hline Total BEE score & 0.9 & 0.8 & 0.7 & 0.6 \\
\hline BEE Rank & B- & B- & B- & B- \\
\hline
\end{tabular}

Source: (Author, 2011)

With some careful considerations when entering justification of each data sheet, all assessment results are able to be analyzed and evaluated. In QUD, some problems depicted some traditional condition of kampungs, such as lack of formation the built environment of kampungs, less number of open space and vegetation, less water conservation, lack of standard of building, pathway, and other infrastructure, as well as lack condition of environment physic brought some limitation of QUD-1 score. In QUD-2, all items emerge to be a standard level or in a low level of quality management/technique, except transportation system that really cannot be measured within standard category. Among environment 
quality, QUD-3 results the highest average. In contrast, in LRUD for kampungs, LR-1 totally gets higher score than other LRs, since the other LRs (LR-2 and LR-3) contain transport and traffic criteria that always results minimum standard. All of these analyses clearly explained through the radar chart in each figure of the results.

The measurement results with the LEED-ND primarily covers 3 major aspects of smart location and linkage (SLL), neighborhood pattern and design (NPD), and green infrastructure and buildings (GIB), as well as an additional aspect of innovation in design process (IDP) in case that there additional measurement may not be addressed by a LEEDND rating system. In general, as presented in Table 3 we can see that the kampungs are able to reach big enough points from SLL aspect, because of their prime location in the city center is very beneficial for communitries to perform daily activities. NDP part is actually also quite promising, especially indicators related to the density and mix-used activities. And as expected, on GIB aspect, the traditional kampung seems still very low in using the latest innovations in line with some efforts towards a green environment. From the results of LEED-ND, the measured kampungs in Yogyakarta City yield points range between 46 (Kampung B) to 59 (Kampung D). These ranges show that the basic conditions of the kampungs have strong and suitable characteristics for some adjustments of sustainable development. Kampung Prawirodirjan (Kampung D) as a standard of existing kampungs in Yogyakarta City can be a benchmark and will be able to explain a fairly good quality standards from most of the kampung conditions in the city (in LEED-ND it reached almost gold). These conditions would be very possible to obtain a higher point, if there are various means related to the sustainable path that appropriately direct the development of kampungs based on more powerful sustainable strategies.

In detail, the results of LEED-ND have almost similar achievement with CASBEE-UD, especially in showing the basic conditions of the kampung settlement where dominantly still shows some limitations in the environmental performances. In addition to the kampung locations in the city center that are very profitable for the activities of communities inside, the kampung actually has significant strength in presenting a rigid and compact development which is very typical in terms of neighborhood design. However, this condition is not yet supported by a adequate network of mobility set out in a TDM (transport demand management) that consists of transport system, street condition, and other relevant facilities. The kampungs in LEED-ND's results also produce maximum points in term of community involvement in the existing development. Once again, this shows that the advantage of the kampung in social interaction aspect is high and promising as sosial capital in future development. It is also very significant aspect to facilitate an achievement target for more socially sustainable condition. Meanwhile, related to the GIB aspect, the kampungs really need a touch of innovation in management of their physical environments. This can be seen in Kampung Terban Utara (kampung A), where some innovations and development approaches that have introduced and delivered by Romo Mangun were able to be accommodated in the design and process innovation category, thus helping raise the obtained points. 
Table 3: Comparison of LEED-ND Assessment Results among the Measured Kampungs

\begin{tabular}{|l|l|l|l|l|}
\hline Category & Kampung A & Kampung B & Kampung C & Kampung D \\
\hline Smart Location and Linkage (SLL) & $20 / 27$ & $20 / 27$ & $18 / 27$ & $22 / 27$ \\
\hline Neighborhood Pattern and Design (NPD) & $11 / 44$ & $11 / 44$ & $15 / 44$ & $17 / 44$ \\
\hline Green Infrastructure and Buildings (GIB) & $5 / 29$ & $3 / 29$ & $4 / 29$ & $3 / 29$ \\
\hline Innovation and Design Process (IDP) & $5 / 6$ & $0 / 6$ & $0 / 6$ & $0 / 6$ \\
\hline LEED Points & $52 / 110$ & $46 / 110$ & $57 / 110$ & $59 / 110$ \\
\hline Certification & Silver & Certified & Silver & Silver \\
\hline $\begin{array}{l}\text { Note: } \\
\text { Points category: Certified: 40-49 points, Silver: } 50-59 \text { points, Gold: } 60-79 \text { points, Platinum: } 80+\text { points }\end{array}$ \\
Source: (Author, 2011) \\
\hline
\end{tabular}

Finally, from both CASBEE-UD and LEED-ND result's point of view, the paper has once more underlined that the urban kampung conditions in one hand offer some potentials andchallenges, such as strategic location in the city center that can raise a convenience level of delivering daily life that as represented by distance to community center, daily life facilities, medical, and school. Indeed, it is traditionally influenced by higher density of physical environment of the urban kampungs with a compact social community interaction, and supported by the existence of mixed use between dwelling and non-dwelling land. In the other hand, many aspects should be considered and involved if a sustainable urban development may be really introduced, such as transport intensification planning, scenario to strengthen socio-economic of the community by some related development approaches, and other relevant strategies. The other important aspect is an introduction of some innovations of green environment activities. Standards of environmental green performance of environment, including its infrastructure and buildings, which is increasing demand of global development can also be immediately tested. Nevertheless, some efforts need to be tailored to the local wisdom of the kampungs that has deep roots and are proven to be advantageous in daily life of the urban kampungs. Moreover towards a further applicable measurement, it is necessary to firstly combine these results with detailed compactness indicators in the kampungs to clearly describe some relevant strategies for resilient city concept through a kampung oriented development (KOD).

\section{Conclusion}

Important actions with respect to the sustainable development implementation, mainly to create sustainable urban form, the urban kampungwhich represents an important spatial unit for social, economy, and physical entity in Indonesian urban structure would take an important role to the realization process of compactness development as main concept of sustainable urban form. A kampung oriented development (KOD) has been interrelated as an underlying model for compactness development through comprehensive policies using the urban kampungs as focus areas. These developments should be strategic alternatives that can encompassseveral intensive developments based on characteristics of the kampung. Measurement of the kampung conditions based on a standard approach must be done first to put real condition of kampungs and to provide relevant strategies in coping with the main problems. This step also meets with demand of high performance building and environment movement worldwide recently. The CASBEE-UD (Comprehensive Assessment System for Building Environmental Efficiency for Urban Development)that developed in Japan and the LEED-ND (Leadership in Energy and Environmental Designfor Neighborhood Development) 
that popularly grown astwo of leading building and environment assessment tools recently are used to assess 4 (four) kampungs in Yogyakarta City as relevant case studies.

The CASBEE-UD and LEED-ND take complex arrays of numerical and non-numerical data and provides a score or point that indicates the comprehensive performance of environment according to the scoring and weighting system built into the method. Principally, the CASBEE-UD method evaluates the environmental efficiency (eco-efficiency) of the building or targeted area by considering $Q$ for Quality to indicate environmental quality and efficiency of inside of the boundary and L for Loading for environmental burdens outside the boundary. This Building Environmental Efficiency or BEE is an attempt to describe the eco-efficiency of the building or targeted areas. While the LEED-ND more places emphasis on the design and construction elements that bring complex of buildings together into a neighborhood, and relate the neighborhood to its larger region and landscape within certain required credits. Based on application of the CASBEE-UD and LEED-ND's measurement procedure for 4 kampungs, indicated that the measured kampungs still have limited performances. In term of the CASBEE-UD, their BEEs do not exceed1.00, and categorized as B- (Fairly Poor). In term of the LEED-ND results, these performances predominantly are located in the range criteria between certified (lower points) and silver (less higher points). These results have clarifiedthat generally environmental performances in the kampungs are still quite far from the ideal standard of sustainability. However, these findings would bring some fruitful relevancies for further appropriate approaches and modified strategies related to improvement of the urban kampung conditions and in particular linked more focus to the objectives of kampung oriented development (KOD).

\section{References}

Biro Pusat Statistik (2010) Yogyakarta in Figure 2007, Statistics Bureau Yogyakarta, Yogyakarta.

Guinness, P. (1986) Harmony and Hierarchy in a Javanese Kampung, Oxford University Press, Singapore.

Institute for Building Environmental and Energy Conservation (IBEC) (2007), Comprehensive Assessment System for Building Environmental Efficiency for Urban Development: Technical Manual 2007 Edition Tool-21, IBEC, Tokyo.

Kawazu, Y., Shimada, N, Yokoo, N., Oka,T. (2005), "Comparison of the assessment results of BREEAM, LEED, GBTool and CASBEE", Proceedings of TheWorldSustainableBuildingConference2005,27 - 29 September 2005, Tokyo,, 17001705.

Mc. Gee, T. G. (1996) “On the Utility of Dualism: The Informal Sector and Mega-Urbanization in Developing Countries", Regional Development Dialogue, Vol. 17 No.1, 1-15.

Murakami, S (2008), Promoting Eco-Model Cities to Create a Low-Carbon Society, Keynote Speech on International Seminar on Promoting the Eco-Model Cities for the Low Carbon Society, Dec. 14, 2008.

Nas, P. J. M. (1987) The Indonesian City, Foris Publications, Dordrecht.

Newman, P., Beatley, T., Boyer, H. (2009) Resilient Cities: Responding to Peak Oil and Climate Change, Island Press, Washington D.C.

Roychansyah, M.S. (2008) "Compact City Development Model in Indonesia: A Kampung Oriented Development", Proceeding of International Seminar on Green Architecture and Environment: Towards Green Compact Cities, Makassar, Oktober 14, 2008, pp. 29-49.

Roychansyah, M.S. (2009) “Towards Kampung Oriented Development: Measuring 
Sustainability Performance of Kampungs Using CASBEE Application", Proceeding of 1st CONVEESH and 10th SENVAR, Manado, October 27, 2009, pp. B-VI-3-1 - B-VI-3-13.

Roychansyah, M.S.; Diwangkari, A. (2009), "Kampung Oriented Development Model: A Rapid Appraisal of Local Communities", Proceeding of CIB - W110 Meeting and Conference "Sustainable Slum Upgrading in Urban Areas", Surakarta, 16 April 2009, pp. 119-134.

Setiawan, B. (2003), "Informal Settlement (Kampung) in Indonesian Cities: Temporary or Permanent Solution?", Working Paper, Department of Architecture, Gadjah Mada University: Internal Publication, Yogyakarta.

United States Green Building Council (USGBC) (2007) LEED for Neighborhood Development Rating System: Pilot Version, USGBC, Washington D.C. 